\title{
A New Lupan type Triterpene Butilinol from Viburnum grandiflorum
}

\author{
Zahid Iqbal Awan*, Habib-ur-Rehman' Khawaja Ansar Yasin and \\ Fiaz Aziz Minhas. \\ (Department of Chemistry, University of Azad Jammu and Kashmir, Muzaffarabad-13100, Pakistan)
}

\begin{abstract}
The isolation and structural studies on the chemical constituents of Viburnum grandiflorum are described. The medicinal properties of the plant are also described. The mentholic extract was subjected to the preparative thin layer chromatography (PTLC) test experiments to investigate the isolation pattern. Based on the PTLC test experiments, the extract was subjected to the silica gel column chromatography. The column was eluted with increasing polarities of organic solvents. This afforded several fractions. The fractions were rechromatographed on silica gel column to afford a new lupan type triterpene butilinol (1) with several known compounds $i$. e. oleanolic acid (2), ursolic acid (3), $\beta$-sitosterol (4), butilinic acid (5), butilin (6), $\alpha$-amyrin (7) and germanicol (8). The compound (6) was not reported previously from the genus Viburnum. This therefore represents its first report from Viburnum grandiflorum. The compounds (2) and (4) have been previously reported from Viburnum pronifolium while the compounds (3) and (8) from Viburnum opulus and Viburnum erubescens, respectively. This represents the first report of the presence of these compounds in Viburnum grandiflorum. The structures of the above compounds were identified on the basis of spectral data (UV, IR, Mass, $\left.{ }^{1} N M R,{ }^{13} C-N M R\right)$ and literature evidences. The hexane and ethyl acetate soluble portions of the methanolic extract showed significant antifungal activity, while the chloroform soluble portion and the remaining methanol extract showed moderate activity.
\end{abstract}

Key words: Viburnum grandiflorum, isolation, triterpene, butilinol, antifungal

\section{Introduction}

Natural products particularly those obtained from plant species are found to possess biological active compounds. As different plant contains different activity spectrums, they are being used and investigated further to know their pharmacological potential. Viburnum is one of the genus found to possess a wide variety of important biological activities. It contains about 200 species, distributed in the temperate and subtropical regions of Asia, North America and Malaysia, only 21 of which have been studied chemically. The six species Viburnum tinus, Viburnum opulus, Viburnum mullaha D. don, Viburnum cotinifolium D. don, Viburnum cylindricum and Viburnum foetns Dene are found in the Northern Pakistan and in the State of Jammu and Kashmir $[1,2]$. These species find use in the folk medicine system for their diuretic, antispasmodic and sedative properties mainly on uterine excitability [3-5]. Viburnum species characteristically contain Irridoids, terpenoids, coumarins and flavones. The rare vibsane diterpenoids e.g. vibsanin B however, have been isolated from the leaves of Viburnum species [6,7]. As part of the search for new terpenoids in Viburnum species, the chemical constituents of the leaves, bark, stem, and roots of the Viburnum grandiflorum have been studied.

The extract of the plant also showed antioxidant, antimicrobial, antiseptic, antibacterial, anthelmintic, anti-neoplastic, anti-malarial, trypanocidal, anti-rheumatic, anti-inflammatory, anti-hyperlipidemic, antiestrogenic, hepatoprotective, anti-carcinomic, higher anti-cancerogenic, anti-arthritic, anti-diabetic, antinociceptive and antifungal activities [8-11]. The methanolic extract of the plant showed strong activity in an antifungal assay. It was subsequently divided into hexane, chloroform, ethyl acetate, and methanol fractions. The hexane and ethyl acetate fractions showed good antifungal activity, whereas chloroform and methanol extract showed moderate antifungal activity.

The medicinal importance and bioactivity of Viburnum grandiflorum prompted us to carry out phytochemical investigations on this species.

\section{Results And Discussion}

Butilinol (1) - The fractions obtained from the parent column (30-43) using Petroleum ether/ Chloroform (60$70 \%$ ) as solvent system was combined on the basis of comparative TLC. This mixture was re-chromatographed on flash silica with Chloroform/Ethyl Acetate as the solvent system. The pure compound (1) was eluted with Chloroform/ Ethyl Acetate (7.0:3.0). 
The UV (Methanol) spectrum of the compound (1) showed $\lambda$ max absorptions at $389 \mathrm{~nm}, 226 \mathrm{~nm}$ and $200 \mathrm{~nm}$ characteristics for lupan class of triterpenes. The IR spectrum showed absorptions at $3430(\mathrm{OH}), 3070$, 1635 and 880 (terminal methylens).

The molecular ion peak was established by HRMS at $456.10 \mathrm{~m} / \mathrm{z}$ corresponding to the molecular formula $\mathrm{C}_{30} \mathrm{H}_{50} \mathrm{O}_{2}$, indicating seven degrees of un-saturations in the molecule. Besides the molecular ion peaks, the EIMS showed other prominent fragmented ion at $\mathrm{m} / \mathrm{z} 423.1,302.0,248.0,207.0,189.1,135.0,95.0$ and 55.0, characteristics of lupan group of triterpenes.

The ${ }^{1} \mathrm{H}-\mathrm{NMR}\left(400 \mathrm{MHz}, \mathrm{CDCl}_{3}\right.$ ) spectrum of (1) showed 50 proton resonances in the molecule. Two singlets at $\delta 4.72$ and $\delta 4.59$ ascribable to an endomethylene proton. This showed $\alpha$-stereochar of the side chain, as in case of $\beta$-stereochar, the two methylenes protons should have appeared as two singlets at $\delta 3.47$ and $\delta 4.21$.

The ${ }^{13} \mathrm{C}$-NMR spectrum of the compound showed 31 carbon resonances in the molecule. The multiplicity of carbon signals was determined by the DEPT experiments with the pulse angle $45^{\circ}, 90^{\circ}$ and $135^{\circ}$. On the basis of the DEPT experiments six signals were found to be of methynes, thirteen of methylenes and six of methyls. The remaining six signals in the Broad Band spectrum were assigned to the quaternary carbons in the molecule. The carbon chemical shifts were compared with the betulinic acid. Most of the carbon resonances were found to be similar. However the acid carbon signal of acid was absent. Therefore number of quaternary carbons is reduced to be six. This shows that the compound in hand does not have acid functionality in it. The methyl signals of both the molecules were same in number and in the value of chemical shifts. The comparison of the methylenes signals showed that our molecule possess two methylenes signals $\delta 68.9$ and $\delta 22.97$ which were not present in butilinic acid molecule. The methylene signal at $\delta 28.01$ was another difference in our molecule (Table 1).

The compound (1) was searched in the library available at HEJ institute of chemistry Karachi including science finder in digital library at LEJ and in dictionary of natural products but found no reference of the data and structure, so it is believed that the compound (1) is a new compound (Figure 1).

Oleanolic Acid (2) - The compound (2) was isolated through silica gel column chromatography. The column was eluted with petroleum ether/ethyl acetate (7.5:2.5). This afforded 30 fractions. The 12th fraction was subjected to the PTLC with petroleum ether/ ethyl acetate (8.5:1.5) as the solvent system. This afforded a pure compound (2) as an amorphous material which gave positive color reactions of triterpenes.

The UV (MeOH) spectrum of compound (2) showed $\lambda \max$ absorptions at 203 characteristic of oleanane class of triterpenes. The IR spectrum showed absorption bands for hydroxyl group $\left(342 \mathrm{~cm}^{-1}\right)$ and of acid carbonyl function $\left(1705 \mathrm{~cm}^{-1}\right)$.

The molecular ion peak was established by HRMS at $\mathrm{m} / \mathrm{z} 456.343$ corresponding to the molecular formula $\mathrm{C}_{30} \mathrm{H}_{48} \mathrm{O}_{3}$ indicating seven degrees of un-saturation in the molecule. Besides the molecular ion peak, the EIMS showed other prominent fragment ions at $\mathrm{m} / \mathrm{z} 248,203,175,133,95$ and 69 , which were characteristic for $\Delta^{12}$-amyrin skeleton. ${ }^{12,13}$ The mass fragmentation indicated that the hydroxyl group was located in ring $\mathrm{A}$ instead of in ring B, C, D or E as fragment of $\mathrm{m} / \mathrm{z} 248$ in that case would not have been obtained.

The carboxy group was also present in this fragment and the ready loss of this group from the fragment A was in agreement with its positioning at C-17. Another fragment at $\mathrm{m} / \mathrm{z} 189$ was also formed by the fragmentation of A; probably involve the loss of carbon 17 along with the $\mathrm{COOH}$ group with a double hydrogen transfer to afford the conjugated allylic cation.

The ${ }^{1} \mathrm{H}-\mathrm{NMR}$ spectrum $\left(\mathrm{CHCl}_{3}, 400 \mathrm{MHz}\right)$ of compound (2) showed the presence of $\mathrm{H}-12$ olefinic proton resonating as $1 \mathrm{H}$ triplet at $\delta 5.25(\mathrm{~J}=3.5 \mathrm{~Hz}$,). Another downfield triplet at $\delta 3.14(\mathrm{~J}=6.8 \mathrm{~Hz})$ corresponds to $\mathrm{H}-3 \alpha$ [35-40]. A $1 \mathrm{H}$ double doublet at $\delta 2.78$ was assigned to $\mathrm{H}-18$ on the basis of its chemical shift as well as multiplicity pattern reported for $\mathrm{H}-18$ with $\beta$-configuration. The spectrum also showed signals for seven methyl groups. The tertiary natures of these methyl groups were evident from their sharp singlet, in the spectrum.

The ${ }^{13} \mathrm{C}-\mathrm{NMR}\left(\mathrm{CHCl}_{3}, 400 \mathrm{MHz}\right)$ of the compound (2) showed a total of thirty carbon resonances (Table 1). These signals were classified into methyls, methylenes and methines on the basis of DEPT experiments. The quaternary carbons were identified from broad band decoupled ${ }^{13} \mathrm{C}-\mathrm{NMR}$ spectrum. The structure (2) was further established by comparison of spectra and physical data to the literature [12-14]. (Figure 2).

Ursolic Acid (3) - The fractions (30-43) obtained from the parent column eluted with chloroform/ethyl acetate $(8.0: 2.0)$ as the solvent system, were combined on the basis of comparative TLC. The material thus obtained was re-chromatographed with chloroform/ethyl acetate (9.9:0.1) to afford the pure compound (3) as white powdered material.

The HRMS indicated the molecular ion peak at 456.000 consistent with the molecular formula $\mathrm{C}_{30} \mathrm{H}_{48} \mathrm{O}_{3}$ indicating seven degrees of un-saturations in the molecule. 
The UV (MeOH) spectrum of compound (3) showed $\lambda$ max absorptions at 202 characteristic of ursane class of triterpenes. The IR $\left(\mathrm{CHCl}_{3}\right)$ showed absorption bands for $\mathrm{COOH}\left(3400 \mathrm{~cm}^{-1}-2650 \mathrm{~cm}^{-1}\right),(2900-2810$ $\left.\mathrm{cm}^{-1}\right)$ and tri-substituted double bond $\left(1690 \mathrm{~cm}^{-1}, 1640 \mathrm{~cm}^{-1}\right.$ and $\left.108 \mathrm{~cm}^{-1}\right)$

$\mathrm{C}_{30} \mathrm{H}_{48} \mathrm{O}_{3},\left(\mathrm{M}^{+} 456\right)$, m.p. $285^{\circ} \mathrm{C}$, [ $\left.\alpha\right] \mathrm{D}^{+} 70^{\circ}\left(\mathrm{CHCl}_{3}\right)$ is a triterpenic acid which forms a methyl ester, $\mathrm{C}_{31} \mathrm{H}_{50} \mathrm{O}_{3}$ $\left(\mathrm{M}^{+} 470\right)$, m.p. $168^{\circ} \mathrm{C}$, $[\alpha] \mathrm{D}^{+} 58^{\circ}\left(\mathrm{CHCl}_{3}\right)$, with diazomethane and a monoacetate, $\mathrm{C}_{32} \mathrm{H}_{50} \mathrm{O}_{4}\left(\mathrm{M}^{+} 498\right)$, m.p. $290^{\circ} \mathrm{C},[\alpha] \mathrm{D}^{+} 70^{\circ}\left(\mathrm{CHCl}_{3}\right)$, with $\mathrm{AC}_{2} \mathrm{O} / \mathrm{Py}$. It was identified as ursolic acid by direct comparison of the compound and it's above derivatives with the respective authentic samples $[15,16]$.

The carbon chemical shifts of ursolic acid and oleanolic acid differs significantly in respect of their $\mathrm{C}$ 11, C-12, C-13, C-27 and the carbon concerning their ring E, while remaining carbon atoms have almost identical shift values. Thus the signals for C-11, C-13, C-19, C-21, C-27, C-29 and C-30 of ursolic acid are shifted up field by $\delta 6.3, \delta 5.3, \delta 6.5, \delta 3.3, \delta 2.7, \delta 9.9$ and $\delta 2.4$, respectively compared to those of the corresponding carbon atoms of the oleanolic acid. On the other hand C-12, C-16, C-17, C-18, C-20 and C-22 of the compound appear at low fields by $\delta 2.7, \delta 1.0, \delta 0.8, \delta 11.8, \delta 8.3$ and $\delta 4.2$, respectively (Table 1). Such differences of shift values to be diagnostic of isomeric pairs of ursane and oleanane derivatives and the above results provide further corroboration (confirmation) of the above generalization [17, 18]. (Figure 3).

$\boldsymbol{\beta}$-Sitosterol (4) - The ethyl acetate extract of the plant was subjected to the flash column chromatography. The column was eluted with petroleum ether /ethyl acetate (8.0:2.0) as solvent system. The fractions 50-70 were combined and re-chromatographed with petroleum ether /ethyl acetate (7.5:2.5) to afford the pure compound (4) as a white crystalline material.

The UV (MeOH) spectrum of compound (4) showed $\lambda$ max absorptions at $210 \mathrm{~nm}$, which indicated the absence of a conjugated system and the presence of an isolated $(\mathrm{C}=\mathrm{C})$ double bond. Other absorptions were at $227 \mathrm{~nm}, 305 \mathrm{~nm}$ and $313 \mathrm{~nm}$ characteristic for the sterol class of triterpenes. The IR $\left(\mathrm{CHCl}_{3}\right)$ showed absorption bands for hydroxyl $\left(3400 \mathrm{~cm}^{-1}\right)$ and tri-substituted double bond $\left(3025 \mathrm{~cm}^{-1}, 1410 \mathrm{~cm}^{-1}\right.$ and $\left.1250 \mathrm{~cm}^{-1}\right)$.

The HRMS indicated the molecular ion peak at 414.4386 consistent with the molecular formula $\mathrm{C}_{29} \mathrm{H}_{50} \mathrm{O}$, indicating five degrees of un-saturation in the molecule.

Other major fragmented peaks were recorded at $399[\mathrm{M}-\mathrm{Me}]^{+}, 396\left[\mathrm{M}-\mathrm{H}_{2} \mathrm{O}\right]^{+}, 381\left[\mathrm{M}-\mathrm{H}_{2} \mathrm{O}-\mathrm{Me}\right]^{+}$.Other abundant ion peaks were observed at $\mathrm{m} / \mathrm{z} 329\left[\mathrm{M}-\mathrm{C}_{7} \mathrm{H}_{5}-\mathrm{H}_{2} \mathrm{O}\right]^{+}$and $303\left[\mathrm{M}-\mathrm{C}_{7} \mathrm{H}_{9}-\mathrm{H}_{2} \mathrm{O}\right]{ }^{+}$which were characteristic for B-sterol with double bond at C-5. The presence of mass fragmented ion peaks at $\mathrm{m} / \mathrm{z} 273$ and 255 corresponded to [M-side chain $]^{+}$and $\left[\mathrm{M} \text {-side chain- } \mathrm{H}_{2} \mathrm{O}\right]^{+}$, respectively.

${ }^{1} \mathrm{H}-\mathrm{NMR}$ data showed similarity of (4) to that reported for $\beta$-sitosterol $[19,20]$. Presence of doublet of double doublet at $\delta 3.51$ and a doublet at $\delta 5.34$ in the ${ }^{1} \mathrm{H}$-NMR spectrum indicated that the substance in hand may be $\beta$-sitosterol. It was also confirmed through Co-TLC and mixed melting point with the authentic sample of $\beta$-Sitosterol (Figure 4).

Butilinic Acid (5) - The fractions 30-43 were combined on the basis of comparative TLC experiment. This mixture was re-chromatographed by using flash silica and chloroform/ethyl acetate (7.0:3.0) as the solvent system to afford the compound (5).

The molecular ion peak was established by HRMS at $\mathrm{m} / \mathrm{z} 456.1000$, corresponding to the molecular formula $\mathrm{C}_{30} \mathrm{H}_{50} \mathrm{O}_{3}$ indicating seven degrees of un-saturation in the molecule. Besides the molecular ion peak, the EIMS showed other prominent fragmented ion at $\mathrm{m} / \mathrm{z}$ 248,189,175,119, 93 and 55, characteristic of lupan group of triterpenes and its spectral data were identical with those of an authentic sample of butilinic acid.

Two singlets at $\delta 4.76$ and 4.91 ascribable to an endomethylene proton. This showed $\alpha$-stereochemistry of the side chain as in case of $\beta$-stereochemistry, the two-methylene protons would appear as two singlets at $\delta$ 3.71 and $\delta 4.18[21]$.

The mass spectrum of (5) exhibited the molecular ion peak at $\mathrm{m} / \mathrm{z}$ 456.1000. In addition prominent peaks at $\mathrm{m} / \mathrm{z} 248$ and 203 were observed in the mass spectrum of both oleanolic acid and butilinic acid. From the above results it was presumed that the $\mathrm{D} / \mathrm{E}$ ring in butilinic acid was the same as that of oleanolic acid.

On comparison of ${ }^{13} \mathrm{C}$-NMR chemical shifts of oleanolic acid and butilinic acid, the data for the rings $\mathrm{C} / \mathrm{D} / \mathrm{E}$ were same. However large difference in the chemical shifts of C-3 and C-23 was apparent. The chemical shifts of protons in the rings $\mathrm{A} / \mathrm{B}$ were similar to those of hederagenin (Table 1). Therefore, the rings $\mathrm{D} / \mathrm{E}$ of butilinic acid had the same skeleton as oleanolic acid and the presence of a carbinol group in ring-A was confirmed. The ${ }^{13} \mathrm{C}$-NMR assignments were made on the basis of comparison of the ${ }^{13} \mathrm{C}$-NMR data of (5) with that of oleanolic acid and hederagenin (Figure 5).

Betulin (6) - Compound (6) was obtained as white needles. The UV spectrum (MeOH) of the compound exhibited $\lambda$ max absorptions at $200 \mathrm{~nm}$ and $204 \mathrm{~nm}$, indicating the presence of lupeol skeleton. The IR spectrum showed absorption bands at $3430 \mathrm{~cm}^{-1}(\mathrm{OH}), 3070 \mathrm{~cm}^{-1}, 1635 \mathrm{~cm}^{-1}$ and $880 \mathrm{~cm}^{-1}$ (terminal methylene group).

The HRMS exhibited the molecular ion peak at $\mathrm{m} / \mathrm{z} 442.3790$, corresponding to the molecular formula $\mathrm{C}_{30} \mathrm{H}_{50} \mathrm{O}_{2}$ indicating six degrees of un-saturation in the molecule. 
The EIMS of the compound (6) exhibited diagnostic peaks at $\mathrm{m} / \mathrm{z} 442[\mathrm{M}]^{+}, 424\left[\mathrm{M}-\mathrm{H}_{2} \mathrm{O}\right]^{+}, 411,234$, $220,207,203,189,175$ and 161, which were characteristic of pentacyclic triterpenes with an isopropenyl group.

The ${ }^{1} \mathrm{H}-\mathrm{NMR}$ spectrum of the compound (6) displayed signals due to six tertiary methyls at $\delta 1.35, \delta$ $1.00, \delta 0.96, \delta 0.95, \delta 0.80$ and $\delta 0.74$. It also showed a $1 \mathrm{H}$ doublet $(\mathrm{J}=12.0 \mathrm{~Hz})$ due to carbinolic proton at $\delta$ 3.31. Its chemical shifts and coupling constant led us to assign $\beta$-configuration to the hydroxyl group at C-3. Another $1 \mathrm{H}$ doublet at $\delta 3.78(\mathrm{~J}=10.69 \mathrm{~Hz}$, ) could be assigned to the methylene carbon attached to the hydroxyl group. The proton signals of $\delta 4.66$ and $\delta 4.56$ indicated the exomethylene protons.

The ${ }^{13} \mathrm{C}-\mathrm{NMR}$ assignments of various carbon atoms were clarified by DEPT experiments which revealed the presence of six methyl, twelve methylene, five methane carbon and six quartnary carbon atoms in the molecule ${ }^{17}$ (Figure 6).

a-Amyrin (7) - The fraction 76 was subjected to the silica gel column chromatography. The fraction eluted with n-hexane /ethyl acetate (8.0:2.0) was subjected to the PTLC with n-hexane/ethyl acetate (9.0:1.0) as the solvent system. This afforded a pure compound (7).

The UV spectrum $(\mathrm{MeOH})$ of the compound (7) showed absorptions at $367 \mathrm{~nm}$ and $390 \mathrm{~nm}$. The UV spectrum was typical of the amyrin skeleton. The IR $\left(\mathrm{CHCl}_{3}\right)$ spectrum exhibited absorption bands for hydroxyl $\left(3430 \mathrm{~cm}^{-1}\right)$ and tri-substituted double bond $\left(3045 \mathrm{~cm}^{-1}, 1650 \mathrm{~cm}^{-1}\right.$ and $\left.815 \mathrm{~cm}^{-1}\right)$.

The EIMS of the compound (7) showed the molecular ion peak at $\mathrm{m} / \mathrm{z} 426.2000$, corresponding to the molecular formula $\mathrm{C}_{30} \mathrm{H}_{50} \mathrm{O}$ indicating six degrees of un-saturation in the molecule. The mass spectrum of the compound (7) showed characteristic fragmentation pattern of amyrin skeleton with double bond at C-12 [22].

The ${ }^{1} \mathrm{H}-\mathrm{NMR}$ spectrum [400 $\mathrm{MHz} \mathrm{CDCl}_{3}$ ] of the compound (7) showed signals for eight tertiary methyl groups at $\delta 0.79, \delta 0.80, \delta 0.91, \delta 0.94, \delta 0.97, \delta 1.05$ and $\delta 1.09$. It further exhibited $1 \mathrm{H}$ double doublet at $\delta 3.21$ $\left(\mathrm{J}_{1}=4.8 \mathrm{~Hz}, \mathrm{~J}_{2}=8.8 \mathrm{~Hz}\right)$ and a $1 \mathrm{H}$ triplet at $\delta 5.13(\mathrm{~J}=2.7 \mathrm{~Hz}, \mathrm{~J}=5.6 \mathrm{~Hz})$, assigned respectively.

The ${ }^{13} \mathrm{C}$-NMR (Broad Band and DEPT) spectra of the compound (7) gave more reliable support for the above conclusions including identity and stereochemistry because the carbon signals exactly corresponded to those reported for $\alpha$-amyrin [23]. (Figure 7).

Germanicol (8) - The fraction eluted with hexane/chloroform (1.0:1.0) was further purified through repeated crystallization to yield the compound (8).

The HRMS of the compound (8) showed the molecular ion peak at $\mathrm{m} / \mathrm{z} 426.3839$, corresponding to the molecular formula $\mathrm{C}_{30} \mathrm{H}_{50} \mathrm{O}$ indicating six degrees of un-saturation in the molecule.

The IR spectrum $\left(\mathrm{CHCl}_{3}\right)$ of the compound showed absorption bands for hydroxyl $\left(3600 \mathrm{~cm}^{-1}\right)$ and trisubstituted double bond $\left(3030 \mathrm{~cm}^{-1}, 1630 \mathrm{~cm}^{-1}\right.$ and $\left.855 \mathrm{~cm}^{-1}\right)$.

The electron impact mass spectrum EIMS of the compound (8) showed characteristic fragmentation pattern of amyrin skeleton with double bond at $\mathrm{C}-18$.

The ${ }^{1} \mathrm{H}-\mathrm{NMR}$ spectrum of the compound (8) showed the presence of eight tertiary methyl groups at $\delta$ $1.08, \delta 1.03, \delta 0.98, \delta 0.95, \delta 0.88, \delta 0.77$ and $\delta 0.74$. A downfield sharp singlet at $\delta 4.88$ was assigned to H-18. The double doublet at $\delta 3.19(\mathrm{~J}=10.8 \mathrm{~Hz}, \mathrm{~J}=5.4 \mathrm{~Hz})$ was due to the proton attached to the carbon bearing hydroxyl group [24]. (igire 8).

II.I. Antifungal activities - The antifungal activities of the different fractions of methanolic extract were studied through applying the agar tube dilution protocol, which is one of the most precise and reliable methods. The hexane fraction showed significant activity against Microsporum canis while the ethyl acetate fraction also exhibited significant activity against Aspergillus flavus. The chloroform and methanolic fractions showed moderate activity against Fusarium solani and Microsporum canis respectively at $400 \mu \mathrm{g} / \mathrm{mL}$ of DMSO.

\section{Experimental}

Plant Material - The plant was collected from Sudhan Galli (Muzaffarabad), which lied in Jhelum Valley. Jhelum Valley is located between $34^{\circ} 30$ latitude and $77^{\circ} 98$ longitude. It is bounded in the south of Kaffer Khun, in the North by Leepa Valley in the East by Qazi Nag and West by Domel. It has rugged topography comprising mainly steep slopes and gullies, where limestone rocks are basically common. The climate is variable between lower and higher altitude. January is coldest month of year. Usually winter is longer than summer and is very cold. June is hottest month, but generally the summer is pleasant. Mainstream in the valley is Qazi Nag, which joins at Chinari with river Jhelum. River Jhelum oozes from Chashma Varinag coming from Srinagar (Kashmir).

Instrumentation - UV spectra were recorded on Shimadzu 240 spectrophotometer. IR spectra were measured on JASCO IRA-1 spectrophotometer. Mass spectra were recorded on Finnigan MAT 112 and 312 double focusing mass spectrometer connected to a PDP11/34 computer system. Optical rotations were obtained by using a JASCO DIP-360 polarimeter. NMR spectra were recorded on Bruker AMX 300, Bruker AMX 400 and $500 \mathrm{MHz}$ respectively for ${ }^{1} \mathrm{H}-\mathrm{NMR}$ and at 75,100 and $125 \mathrm{MHz}$ respectively for ${ }^{13} \mathrm{C}-\mathrm{NMR}$. The chemical shifts 
are reported in $\delta(\mathrm{ppm})$ and the coupling constants are in Hz. Merck silica gel $60 \mathrm{~F}_{254}$ pre coated aluminum cards $\left(0.2 \mathrm{~mm}\right.$ thickness) and glass plates (silica gel Merck $\left.\mathrm{GF}_{254}\right)$ were used for analytical (thin layer) and preparative (thick layer) chromatography, while for flash column chromatography (FCC) silica gel Merck $\mathrm{GF}_{254}$ and Merck 9385 were used. Melting points were recorded in glass capillary tubes on BUCHI 535 M.P. apparatus and are uncorrected.

The plant was identified by the Botany department of Azad Jammu and Kashmir University Muzaffarabad and a voucher specimen has been deposited in the Herbarium.

Isolation of (1) - IR (KBr) $v$ max $\mathrm{cm}^{-1}: 3430(\mathrm{OH}), 3070,1635$ and 880; EI-MS m/z (rel. int. \%):456.1 $\left(\mathrm{C}_{31} \mathrm{H}_{50} \mathrm{O}_{2}, \mathrm{M}^{+}\right)$(11.29), 248 (14.16), 207 (25.23), 189.1 (54.30), 135 (32.92), 95 (51.15) and 55 (100); HRMS $(\mathrm{m} / \mathrm{z}): 456.1\left(\mathrm{C}_{31} \mathrm{H}_{50} \mathrm{O}_{2}\right)$.

${ }^{1} \mathrm{H}-\mathrm{NMR}\left(\mathrm{CDCL}_{3}, 400 \mathrm{MHz}\right) \delta: 4.72(\mathrm{~s}, 1 \mathrm{H}), 4.59(\mathrm{~s}, 1 \mathrm{H}), 4.21(\mathrm{t}, \mathrm{J}=12 \mathrm{~Hz} 1 \mathrm{H}), 3.47(\mathrm{~s}, 1 \mathrm{H}), 3.18\left(\mathrm{dd}, \mathrm{J}_{1}=4 \mathrm{~Hz}\right.$, $\left.\mathrm{J}_{2}=4 \mathrm{~Hz}, 1 \mathrm{H}\right), 2.97\left(\mathrm{ddd}, \mathrm{J}_{1}=4 \mathrm{~Hz}, \mathrm{~J}_{2}=8 \mathrm{~Hz}, \mathrm{~J}_{3}=4 \mathrm{~Hz}, 1 \mathrm{H}\right), 2.26(\mathrm{~s}, 1 \mathrm{H}), 2.25(\mathrm{~s}, 1 \mathrm{H}), 2.23(\mathrm{~d}, \mathrm{~J}=4 \mathrm{~Hz}, 1 \mathrm{H}), 2.19(\mathrm{~d}$, $\mathrm{J}=2.8 \mathrm{~Hz}, 1 \mathrm{H}), 2.16(\mathrm{~d}, \mathrm{~J}=3.6 \mathrm{~Hz}, 1 \mathrm{H}), 1.99(\mathrm{~s}, 1 \mathrm{H}), 1.98(\mathrm{~s}, 1 \mathrm{H}), 1.97(\mathrm{~s}, 1 \mathrm{H}), 1.95(\mathrm{~s}, 1 \mathrm{H}), 1.94(\mathrm{~s}, 1 \mathrm{H}), 1.92(\mathrm{~s}$, $1 \mathrm{H}), 1.67(\mathrm{~s}, 3 \mathrm{H}), 1.64(\mathrm{~d}, \mathrm{~J}=4 \mathrm{~Hz}, 1 \mathrm{H}), 1.59(\mathrm{~s}, 1 \mathrm{H}), 1.51(\mathrm{~m}, 4 \mathrm{H}), 1.47(\mathrm{~s}, 1 \mathrm{H}), 1.44(\mathrm{~s}, 1 \mathrm{H}), 1.41(\mathrm{~d}, \mathrm{~J}=4 \mathrm{~Hz}$, $1 \mathrm{H}), 1.38(\mathrm{~s}, 1 \mathrm{H}), 1.35(\mathrm{~s}, 1 \mathrm{H}), 1.30(\mathrm{~s}, 1 \mathrm{H}), 1.28(\mathrm{~s}, 1 \mathrm{H}), 1.24(\mathrm{~s}, 1 \mathrm{H}), 1.20(\mathrm{~d}, \mathrm{~J}=4 \mathrm{~Hz}, 1 \mathrm{H}), 1.17(\mathrm{~d}, \mathrm{~J}=4 \mathrm{~Hz}$, $1 \mathrm{H}), 1.03(\mathrm{~s}, 1 \mathrm{H}), 1.00(\mathrm{~s}, 1 \mathrm{H}), 0.95(\mathrm{~d}, \mathrm{~J}=4 \mathrm{~Hz}, 1 \mathrm{H}), 0.92(\mathrm{~s}, 1 \mathrm{H}), 0.90(\mathrm{~s}, 1 \mathrm{H}), 0.88(\mathrm{~d}, \mathrm{~J}=4 \mathrm{~Hz}, 1 \mathrm{H}), 0.86(\mathrm{~s}$, $1 \mathrm{H}), 0.80(\mathrm{~s}, 3 \mathrm{H}), 0.73(\mathrm{~s}, 3 \mathrm{H}), 0.67(\mathrm{~s}, 1 \mathrm{H})$ and $0.65(\mathrm{~s}, 1 \mathrm{H}) ;{ }^{13} \mathrm{C}-\mathrm{NMR}\left(\mathrm{CHCL}_{3}, 400 \mathrm{MHz}\right) \delta: 150.37(\mathrm{C}-1)$, 109.69 (C-2), 79.02 (C-3), 68.19 (C-4), 56.21 (C-5), 55.43 (C-6), 50.61 (C-7), 49.35 (C-8), 46.87 (C-9), 42.49 (C-10), 40.77 (C-11), 38.89 (C-12), 38.78 (C-13), 38.41 (C-14), 37.26 (C-15), 37.01 (C-16), 34.40 (C-17), 32.17 (C-18), 30.57 (C-19), 29.73 (C-20), 28.01 (C-21), 27.46 (C-22), 25.57 (C-23), 22.97 (C-24), 20.91 (C-25), 19.39 (C-26), 18.33 (C-27), 16.13 (C-28), 16.05 (C-29), 15.34 (C-30) and 14.71 (C-31).

Isolation of (2) - The compound (2) was isolated through silica gel column chromatography. The column was eluted with Pet. Ether/EtOAc (7.5:2.5). The (12th) fraction obtained with was subjected to the PTLC with Pet. Ether/EtOAc (8.5:1.5) as the solvent system. This afforded a pure compound (2) as an amorphous material which gave positive color reactions of triterpenes. IR (KBr) $v \operatorname{max~cc^{-1}}: 3420(\mathrm{OH}), 1705(\mathrm{CO}), 2930,1450$, 1250, 690 and 820; EI-MS (m/z) rel. int. \%): $456\left[\mathrm{C}_{30} \mathrm{H}_{50} \mathrm{O}_{3}, \mathrm{M}\right]^{+}$(2), 248 (100), 207 (17.8), 203 (85), 175 (13.5), 147 (16), 133 (32.8), 119 (28.6), 107 (27), 105 (32.2), 95 (37.9), 69 (93), 57 (70) and 55 (86); ${ }^{1} \mathrm{H}-\mathrm{NMR}$ $\left(\mathrm{CHCL}_{3}, 400 \mathrm{MHz}\right) \delta: 5.28$ (t, J=3.5, 1H, H-12), 3.14 (t, J=6.8 Hz, H-3), 2.78 (dd, J=3.5Hz, 14.0Hz, 1H,H-18), $0.75(\mathrm{~s}, 3 \mathrm{H}), 0.86(\mathrm{~s}, 3 \mathrm{H}), 0.96(\mathrm{~s}, 3 \mathrm{H}), 0.91(\mathrm{~s}, 3 \mathrm{H}), 1.04(\mathrm{~s}, 3 \mathrm{H}), 1.12(\mathrm{~s}, 3 \mathrm{H}), 1.23(\mathrm{~s}, 3 \mathrm{H}) ;{ }^{13} \mathrm{C}-\mathrm{NMR}\left(\mathrm{CHCL}_{3}\right.$, $600 \mathrm{MHz})$ 8: 38.41 (C-1), 27.17 (C-2), 79.01 (C-3), 39.25 (C-4), 55.203 (C-5), 18.31 (C-6), 32.67 (C-7), 37.04 (C-8), 47.603 (C-9), 38.74 (C-10), 23.04 (C-11), 122.67 (C-12), 143.53 (C-13), 41.69 (C-14), 27.67 (C-15), 23.04 (C-16), 46.42 (C-17), 41.179 (C-18), 45.87 (C-19), 30.66 (C-20), 33.79 (C-21), 32.39 (C-22), 28.08 (C23), 15.54 (C-24), 15.3 (C-25), 17.00 (C-26), 25.87 (C-27), 180.06 (C-28), 32. 67 (C-29) and 23.39 (C-30).

Isolation of (3) - The fractions (30-43) obtained from the parent column eluted with $\mathrm{CHCl}_{3} / \operatorname{EtOAc}(8.0: 2.0)$ as solvent system, were combined on the basis of comparative TLC. The material thus obtained was rechromatographed with $\mathrm{CHCl}_{3} / \mathrm{EtOAc}$ (9.9:0.1), to afford the pure compound (3) as white powdered material. EIMS (m/z) rel. int. \%: $456\left[\mathrm{C}_{30} \mathrm{H}_{48} \mathrm{O}_{3}, \mathrm{M}^{+}\right]$(6.1), 438 (4.3), 300 (5.3), 248 (100), 235 (6.2), 291 (14.6), 203 (79.3), 189 (22.8), 175 (12.9), 161 (7.6), 147 (13.8), 133 (47.8), 119 (18.3), 105 (13.5), 95 (16.1), 81 (12.6), 79 (7.2) and $55(12.9) ;{ }^{1} \mathrm{H}-\mathrm{NMR}\left(\mathrm{CHCL}_{3}, 400 \mathrm{MHz}\right) \delta$ : $5.13(\mathrm{t}, \mathrm{J}=4 \mathrm{HZ}, 1 \mathrm{H}), 3.08(\mathrm{t}, \mathrm{J}=8 \mathrm{HZ}, 1 \mathrm{H}), 3.26(\mathrm{~s}, 1 \mathrm{H})$, $3.28(\mathrm{~s}, 1 \mathrm{H}), 3.30(\mathrm{~s}, 1 \mathrm{H}), 3.41(\mathrm{bs}, \mathrm{OH}), 3.80(\mathrm{~s}, 1 \mathrm{H}), 4.00(\mathrm{~s}, 1 \mathrm{H}), 4.02(\mathrm{~s}, 1 \mathrm{H}), 4.10(\mathrm{~s}, 1 \mathrm{H}), 1.15(\mathrm{~s}, 1 \mathrm{H}), 1.17$ $(\mathrm{s}, 1 \mathrm{H}), 1.21(\mathrm{~s}, 1 \mathrm{H}), 1.23(\mathrm{~s}, 1 \mathrm{H}), 1.26(\mathrm{~s}, 1 \mathrm{H}), 1.29(\mathrm{~s}, 1 \mathrm{H}), 1.37(\mathrm{~s}, 1 \mathrm{H}), 1.39(\mathrm{~s}, 1 \mathrm{H}), 1.40(\mathrm{~s}, 1 \mathrm{H}), 1.41(\mathrm{~s}$, $1 \mathrm{H}), 1.48(\mathrm{~d}, \mathrm{~J}=4 \mathrm{HZ}, 1 \mathrm{H}), 1.50(\mathrm{~s}, 1 \mathrm{H}), 1.52(\mathrm{~s}, 1 \mathrm{H}), 1.53(\mathrm{~s}, 1 \mathrm{H}), 1.55(\mathrm{~s}, 1 \mathrm{H}), 1.58(\mathrm{~s}, 1 \mathrm{H}), 1.73\left(\mathrm{ddd}, \mathrm{J}_{1}=4 \mathrm{HZ}\right.$, $\left.\mathrm{J}_{2}=8 \mathrm{HZ}, \mathrm{J}_{3}=12 \mathrm{HZ}, 1 \mathrm{H}\right), 1.80(\mathrm{t}, \mathrm{J}=4 \mathrm{HZ}, 1 \mathrm{H}), 1.89\left(\mathrm{ddd}, \mathrm{J}_{1}=4 \mathrm{HZ}, \mathrm{J}_{2}=8 \mathrm{HZ}, \mathrm{J}_{3}=12 \mathrm{HZ}, 1 \mathrm{H}\right), 2.08(\mathrm{~d}, \mathrm{~J}=8 \mathrm{HZ}$, $1 \mathrm{H}), 0.60(\mathrm{~s}, 1 \mathrm{H}), 0.62(\mathrm{~s}, 1 \mathrm{H}), 0.66(\mathrm{~s}, 3 \mathrm{H}), 0.70(\mathrm{~s}, 3 \mathrm{H}), 0.74(\mathrm{~s}, 3 \mathrm{H}), 0.76(\mathrm{~s}, 3 \mathrm{H}), 0.81(\mathrm{~s}, 3 \mathrm{H}), 0.84(\mathrm{~s}, 3 \mathrm{H})$, $0.87(\mathrm{~s}, 3 \mathrm{H})$ and $0.97(\mathrm{~s}, 3 \mathrm{H}) ;{ }^{13} \mathrm{C}-\mathrm{NMR}\left(\mathrm{CDCL}_{3}, 400 \mathrm{MHz}\right) \delta: 180.51(\mathrm{C}-1), 138.061(\mathrm{C}-2), 77.20(\mathrm{C}-3), 63.37$ (C-4), 47.68 (C-5), 41.93 (C-6), 39.33 (C-7), 36.79 (C-8), 125.35 (C-9), 78.72 (C-10), 55.12 (C-11), 52.70 (C12), 47.43 (C-13), 38.95 (C-14), 38.76 (C-15), 38.53 (C-16), 36.68 (C-17), 32.90 (C-18), 30.53 (C-19), 26.71 (C-20), 24.07 (C-21), 23.12 (C-22), 18.16 (C-23), 27.89 (C-24) 23.34 (C-25), 20.95 (C-26), 16.81 (C-27), 16.72 (C-28), 15.42 (C-29), $15.22(\mathrm{C}-30)$.

Isolation of (4) - The Pet. Ether/EtOAc fraction obtained from the column was subjected to flash chromatography with pet. Ether/EtOAc (7.5:2.5) which gave (4) $10 \mathrm{mg}$.

UV (MeOH), $\lambda \max \mathrm{nm}(\log \varepsilon): 215(0.68), 226(0.843), 305(0.09)$ and $313(0.104)$

EIMS mlz (rel. int. \%): 414[ $\left.\mathrm{C}_{29} \mathrm{H}_{50} \mathrm{O}, \mathrm{M}\right]^{+}(100), 399$ [M-Me $]^{+}$, (35.1), 396[M- $\left.\mathrm{H}_{2} \mathrm{O}\right]^{+}$(49.9), 381[M-Me- $\left.\mathrm{H}_{2} \mathrm{O}\right]^{+}$ (28.5), 329[M- $\left.\mathrm{H}_{2} \mathrm{O}-\mathrm{C}_{5} \mathrm{H}_{7}\right]^{+}$(30.2), 303[M- $\left.\mathrm{H}_{2} \mathrm{O}-\mathrm{C}_{5} \mathrm{H}_{9}\right]^{+}$(31.3), 273 (16.8), 255 (20.6), 213 (26.9), 199 (11.2), 173 (12), 159 (24.5), 145 (28.9), 133 (21.2), 119 (25.0), 105 (31.08), 91 (24.2), 79 (20), 69 (26.4), 57 (36.8) and 43 (94.6); ${ }^{1} \mathrm{H}-\mathrm{NMR}(400 \mathrm{MHz})$ 8: 5.31 (d, J=4HZ, 1H), 3.5 (m, 1H), 2.3 (s, 1H), 2.29 (s, 1H), 2.28 (s, 1H), 2.25 (ddd, J= 4HZ, J= 4HZ, J= 8HZ, 1H), $2.2(\mathrm{~s}, 1 \mathrm{H}), 2.18(\mathrm{~s}, 1 \mathrm{H}), 2.17(\mathrm{~s}, 1 \mathrm{H}), 2.0(\mathrm{~s}, 1 \mathrm{H}), 1.97(\mathrm{~s}, 1 \mathrm{H}), 1.96(\mathrm{~s}$, $1 \mathrm{H}), 1.94(\mathrm{~s}, 1 \mathrm{H}), 1.93(\mathrm{~s}, 1 \mathrm{H}), 1.80(\mathrm{~s}, 1 \mathrm{H}), 1.7(\mathrm{~s}, 1 \mathrm{H}), 1.23(\mathrm{~s}, 3 \mathrm{H}), 0.98(\mathrm{~s}, 3 \mathrm{H}), 0.89(\mathrm{~d}, \mathrm{~J}=4 \mathrm{HZ}, 1 \mathrm{H}), 0.82(\mathrm{~s}$, 
$3 \mathrm{H}), 0.80(\mathrm{t}, \mathrm{J}=7.0 \mathrm{HZ}, 3 \mathrm{H}), 0.78(\mathrm{~s}, 3 \mathrm{H})$ and $0.66(\mathrm{~s}, 3 \mathrm{H}) ;{ }^{13} \mathrm{C}-\mathrm{NMR}\left(300 \mathrm{MHz} \mathrm{CDCL}_{3}\right) \delta: 37.26(\mathrm{C}-1), 31.68$ (C-2), 71.81 (C-3), 42.32 (C-4), 140 (C-5), 121.7 (C-6),31.68 (C-7), 31.91 (C-8), 50.15 (C-9), 36.51 (C-10), 21.09 (C-11), 42.32 (C-12), 14.09 (C-13), 56.78 (C-14), 24.30 (C-15), 28.24 (C-16), 56.07 (C-17), 11.97 (C-18), 19.38 (C-19), 36.14 (C-20), 19.03 (C-21), 33.96 (C-22), 29.68 (C-23), 45.85 (C-24), 29.17 (C-25), 18.77 (C-26), 19.80 (C-27), 23.08 (C-28), 11.85 (C-29).

Isolation of (5) - The fractions (30-43) were combined on the basis of comparative TLC. This mixture was rechromatographed by using flash silica and $\mathrm{CHCl}_{3} / \mathrm{EtOAc}$ (7.0:3.0) as the solvent system to afford the compound (5).

HR-MS (m/z): 414 (Calcd. For $\left.\mathrm{C}_{29} \mathrm{H}_{50} \mathrm{O}, 414\right)$ ); IR KBr $v$ max cm $\mathrm{cm}^{-1}: 3500,1700,1620$; EI-MS m/z (rel. int. \%): $456.1\left(\mathrm{C}_{30} \mathrm{H}_{48} \mathrm{O}_{3}, \mathrm{M}^{+}\right)$(10.38), 423.1 (2.12), 259.0 (3.57), 248.0 (19.49), 189.1 (53.15), 175.0 (20.11), 119.0 (36.82), 93.0 (61.14) and 55.0 (100); HRMS (m/z): $456.1\left(\mathrm{C}_{30} \mathrm{H}_{48} \mathrm{O}_{3}\right) ;{ }^{1} \mathrm{H}-\mathrm{NMR}\left(\mathrm{CDCL}_{3}, 400 \mathrm{MHz}\right): 4.72(\mathrm{~s}$, $1 \mathrm{H}), 4.58(\mathrm{~s}, 1 \mathrm{H}), 3.16\left(\mathrm{dd}, \mathrm{J}_{1}=8 \mathrm{~Hz}, \mathrm{~J}_{2}=12 \mathrm{~Hz}, 1 \mathrm{H}\right), 2.99$, (d, J=4Hz, 1H), $2.96(\mathrm{~d}, \mathrm{~J}=4 \mathrm{~Hz}, 1 \mathrm{H}), 2.93(\mathrm{~d}, \mathrm{~J}=4 \mathrm{~Hz}$, $1 \mathrm{H}), 2.26(\mathrm{~s}, 1 \mathrm{H}), 2.23(\mathrm{~s}, 1 \mathrm{H}), 2.16(\mathrm{~d}, \mathrm{~J}=4 \mathrm{~Hz}, 1 \mathrm{H}), 2.13(\mathrm{~d}, \mathrm{~J}=4 \mathrm{~Hz}, 1 \mathrm{H}), 2.0(\mathrm{~s}, 1 \mathrm{H}), 1.97(\mathrm{~d}, \mathrm{~J}=4 \mathrm{~Hz}, 1 \mathrm{H}), 1.96$ $(\mathrm{s}, 1 \mathrm{H}), 1.94(\mathrm{~d}, \mathrm{~J}=4 \mathrm{~Hz}, 1 \mathrm{H}), 1.67(\mathrm{~s}, 3 \mathrm{H}), 1.63(\mathrm{~s}, 1 \mathrm{H}), 1.62(\mathrm{~s}, 1 \mathrm{H}), 1.59(\mathrm{~m}, 3 \mathrm{H}), 1.35(\mathrm{~s}, 3 \mathrm{H}), 1.24(\mathrm{~s}, 3 \mathrm{H})$, $0.93(\mathrm{~d}, \mathrm{~J}=4 \mathrm{~Hz}, 1 \mathrm{H}), 0.92(\mathrm{~s}, 3 \mathrm{H}), 0.80(\mathrm{~s}, 3 \mathrm{H}), 0.73(\mathrm{~s}, 3 \mathrm{H}), 0.67(\mathrm{~s}, 1 \mathrm{H})$ and $0.65(\mathrm{~s}, 1 \mathrm{H}) ;{ }^{13} \mathrm{C}-\mathrm{NMR}\left(\mathrm{CHCL}_{3}\right.$,

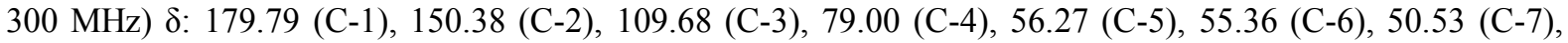
49.29 (C-8), 46.88 (C-9), 42.45 (C-10), 40.71 (C-11), 38.86 (C-12), 38.72 (C-13), 38.39 (C-14), 37.22 (C-15), 37.01 (C-16), 34.34 (C-17), 32.15 (C-18), 30.56 (C-19), 29.98 (C-20), 27.70 (C-21), 27.41 (C-22), 25.51 (C-23), 20.86 (C-24), 19.37 (C-25), 18.29 (C-26), 16.11 (C-27), 16.03 (C-28), 15.33 (C-29) and 14.69 (C-30).

Isolation of (6) - IR KBr $v$ max cm$~_{-1}: 3430,3070,1635$ and 880; $\mathrm{UV}(\mathrm{MeOH}), \lambda \max ^{\mathrm{nm}}(\log \varepsilon): 200(0.574), 204$ (1.043); HRMS: $442.379[\mathrm{M}]^{+}\left(\mathrm{C}_{30} \mathrm{H}_{50} \mathrm{O}_{2}\right), 427\left(\mathrm{C}_{29} \mathrm{H}_{47} \mathrm{O}_{2}\right), 424.36\left(\mathrm{C}_{30} \mathrm{H}_{48} \mathrm{O}_{1}\right), 411\left(\mathrm{C}_{29} \mathrm{H}_{47} \mathrm{O}_{1}\right)$ and 409 $\left(\mathrm{C}_{29} \mathrm{H}_{45} \mathrm{O}_{1}\right)$; EIMS m/z (rel.intensity in \%): $442[\mathrm{M}]^{+}(21), 424\left[\mathrm{M}-\mathrm{H}_{2} \mathrm{O}\right]^{+}(10.6), 411$ (52), 409 (7.3), 3.99 (11.7), 3.85 (10.9), 257 (9.8), 234 (23.8), 220 (16.2), 207 (60.3), 203 (100), 189 (84), 175 (35), 161 (25.4), 147 (29.0), 135 (49.0), 121 (37), 107 (37.9), 95 (50.1), 81 (36.9), 69 (35.01), 55 (28.5) and 44 (45.4); ${ }^{1} \mathrm{H}-\mathrm{NMR}$ (400MHz), $\left(\mathrm{CDCL}_{3}\right) \delta: 4.66(\mathrm{~s}, 1 \mathrm{H}), 4.56(\mathrm{~s}, 1 \mathrm{H}), 3.78(\mathrm{~d}, 1 \mathrm{H}, \mathrm{J}=12 \mathrm{~Hz}), 3.31(\mathrm{~d}, 1 \mathrm{H}, \mathrm{J}=12 \mathrm{~Hz}), 3.17(\mathrm{~m}, 1 \mathrm{H})$, $2.37\left(\mathrm{ddd}, 1 \mathrm{H}, \mathrm{J}_{1}=8 \mathrm{~Hz}, \mathrm{~J}_{2}=4 \mathrm{~Hz}\right), 1.93(\mathrm{~m}, 1 \mathrm{H}), 1.83(\mathrm{~m}, 1 \mathrm{H}), 1.66(\mathrm{~s}, 3 \mathrm{H}), 1.63(\mathrm{~m}, 1 \mathrm{H}), 1.59(\mathrm{~m}, 1 \mathrm{H}), 1.56(\mathrm{~m}$, $1 \mathrm{H}), 1.51(\mathrm{~s}, 6 \mathrm{H}), 1.35(\mathrm{~S}, 3 \mathrm{H}), 1.40(\mathrm{~m}, 1 \mathrm{H}), 1.23(\mathrm{~m}, 1 \mathrm{H}), 1.15(\mathrm{~m}, 1 \mathrm{H}), 1.05(\mathrm{~m}, 1 \mathrm{H}), 1.00(\mathrm{~s}, 3 \mathrm{H}), 0.96(\mathrm{~s}$, $3 \mathrm{H}), 0.95(\mathrm{~s}, 3 \mathrm{H}), 0.80(\mathrm{~s}, 3 \mathrm{H})$ and $0.74(\mathrm{~s}, 3 \mathrm{H}) ;{ }^{13} \mathrm{C}-\mathrm{NMR}$ (400 MHz, CDCL3) $8: 38.73$ (C-1), 27.08 (C-2), 78.89 (C-3), 38.87 (C-4), 55.3 (C-5), 18.31 (C-6), 34.26 (C-7), 40.95 (C-8), 50.43 (C-9), 37.18 (C-10), 20.08 (C-11), 25.24 (C-12), 37.34 (C-13), 42.74 (C-14), 27.42 (C-15), 29.20 (C-16), 28.009 (C-17), 47.81 (C-18), 48.80 (C-19), 150 (C-20), 29.78 (C-21), 33.98 (C-22), 37.99 (C-23), 15.34 (C-24), 16.10 (C-25), 15.99 (C-26), 14.77 (C-27), 60.59 (C-28), 19.09 (C-29), 110 (C-30).

Isolation of (7) - The elute obtained from the column with n-hexane EtOAC (80:20). Separation was carried out over Silica gel by using Pet. Ether. Ethyl Acetate in 8:2 ratios.

UV (MeOH), $\lambda \max ^{\mathrm{nm}}(\log \varepsilon): 367$ (0.0124), 390 (0.0178); IR KBr $v$ max cm ${ }^{-1}: 3510(\mathrm{OH}), 1650$ and 815; EIMS m/z (rel. int. \%): $426\left(\mathrm{C}_{30} \mathrm{H}_{50} \mathrm{O}, \mathrm{M}^{+}\right)(6.93), 411[\mathrm{M}-\mathrm{Me}]^{+}(2.18), 257$ (2.882), 229 (3.72), $218\left[\mathrm{M}^{-} \mathrm{C}_{14} \mathrm{H}_{24} \mathrm{O}\right]^{+}$

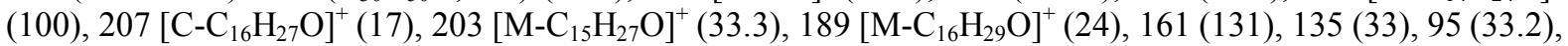
55 (42.9); HRMS (m/z). $426.38\left(\mathrm{C}_{30} \mathrm{H}_{50} \mathrm{O}\right)$; $1 \mathrm{H}-\mathrm{NMR}\left(\mathrm{CDCL}_{3}, 400 \mathrm{MHz}\right): \delta 5.113(\mathrm{t}, \mathrm{J}=2.76 \mathrm{~Hz}, \mathrm{~J}=5.6 \mathrm{~Hz}, 1 \mathrm{H}$, $\mathrm{H}-12$ ), 3.21 (dd, J=4.8 Hz, J=8.8Hz, 1H, H-3), 1.05 (s, 3H, Me-26), 1.009 (s, 3H, Me-27), 0.97 (s, 3H, Me-25), 0.94 (s, 3H, Me-23), 0.91 (br. s. 3H, Me-30), 0.85 (s, 3H, Me-24), 0.80 (s, 3H, Me-28), 0.779 (d, 3H, J=3Hz, Me-29);

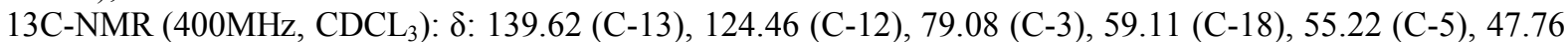
(C-9), 41.78 (C-14), 40.08 (C-8), 41.56 (C-22), 39.69 (C-19), 39.64 (C-20), 39.7 (C-4), 40.03 (C-1), 37.18 (C10), 33.78 (C-17), 32.98 (C-7), 31.28 (C-21), 28.0 (C-15), 28.76 (C-28), 28.4 (C-27), 26.65 (C-16), 27.31 (C-2), 23.4 (C-29), 21.37 (C-30), 18.38 (C-6), 23.39 (C-11), 15.62 (C-23), 15.68 (C-24), 16.9 (C-25) and 17.48 (C26).

Isolation of (8) - This compound was isolated from the chloroform-hexane (1:1) fraction. The fraction was subjected to column chromatography for further purification. Elution with hexane-chloroform (1:9) gave the compound (8) (10 mg).

IR (KBr) $v$ max cm ${ }^{-1}: 3600(\mathrm{OH}), 3030,1630,1467$ and 855; EI-MS m/z (rel. int. \%): $426\left[\mathrm{C}_{30} \mathrm{H}_{50} \mathrm{O}, \mathrm{M}_{+}\right]$(17), 411 (23), 408 (6), 231 (18), 218 (38), 189 (100), 207 (20) and 177 (87); ${ }^{1} \mathrm{H}-\mathrm{NMR}\left(400 \mathrm{MHz}, \mathrm{CDCL}_{3}\right): \delta 4.88(\mathrm{~s}$,

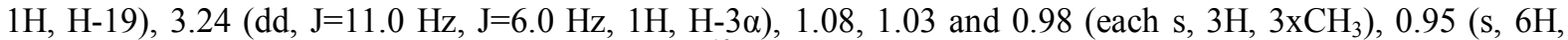
$\left.2 \mathrm{xCH}_{3}\right), 0.88,0.77$ and 0.74 (s, each $\left.3 \mathrm{H}, 3 \mathrm{xCH}_{3}\right),{ }^{13} \mathrm{C}-\mathrm{NMR}\left(400 \mathrm{MHz}, \mathrm{CDCL}_{3}\right): \delta 142.8(\mathrm{C}-18), 129.8(\mathrm{C}-19)$, 79.0 (C-3), 55.7 (C-5), 51.3 (C-9), 43.4 (C-14), 40.9 (C-8), 39.0 (C-13), 39.0 (C-4), 38.5 (C-1), 37.7 (C-22), 37.4 (C-16), 37.3 (C-10), 34.7 (C-7), 34.4 (C-17), 33.4 (C-21), 32.3 (C-20), 31.3 (C-29), 29.2 (C-30), 28.0 (C23), 27.6 (C-15),24.4 (C-2), 26.2 (C-12), 25.3 (C-28), 21.2 (C-11), 18.3 (C-6), 16.7 (C-26), 16.1 (C-25), 15.4 (C-24) and $14.6(\mathrm{C}-27)$. 


\section{Acknowledgements}

The authors are grateful to Prof. Dr. M. I. Chaudhary (H.E.J. Research Institute of Chemistry Karachi, Pakistan) for providing the facility of ${ }^{13} \mathrm{C}-\mathrm{NMR},{ }^{1} \mathrm{H}-\mathrm{NMR}$, HRMS, FAB, UV and IR spectra of compounds.

\section{References}

[1]. E. Nasir, S. I. Ali and R. R. Stewert, Flora of West Pakistan, (Fakhri Printing Press, Karachi: Pakistan, 1972 ) $695-696$.

[2]. R. N. Parker, A Forest Flora for the Punjab with Hazara and Dehli, (Ed. 3rd) (Govt. Printing Press, West Pakistan 1956) 265-275.

[3]. J. A. Nicholson, T. D. Darby and C. H. Jarboe, Proceedings of the Society for Experimental Biology and Medicine, 140, $1972,457$.

[4]. G. Stanic and J. Petricic, J. Farm. Glass.,35, 1979, 231

[5]. L. Tomassini, M. F. Cometa, S. Foddai N. Nicoletti, Phytochemistry, 38(2), 1995, 423-425.

[6]. Y. Fukuyama, M. Hiroyuki, H. Fujji and M. Tajima, Phytochemistry, 60, 2002, 765-768.

[7]. A. Ali, H. El-Gamal, S. K. Wang and C. Y. Duh, Journal of Natural Products, 67, 2004, 333-336.

[8]. T. Fujoka, Y. Kashiwada, R. E. Kilkushi and L. M. Consentino, Journal of Natural Products, 57, 1994,243

[9]. J. F. Mayaux, A. Bousseau, R. Pauwels, T. Huet and Y. Henin, Proceedings of the National Academy of Science, 91, 1994, 3564.

[10]. H. X. Xu, F. Q. Zeng, M. Wan and K. Y. Sim, Journal of Natural Products, 59, 1996, 643.

[11]. S. K. Talpatra, K. M. Shreshtha, M. K. Pal, A. Basak and B. Talpatra, Phytochemistry, 28, $1989,3437$.

[12]. A. Ikuta and H. Itokawa, Phytochemistry, 27(9), 1988, 2813-2815.

[13]. V. U. Ahmad, S. Bano and F. V. Mohammad, Planta Medica, 6, 1985, 521.

[14]. J. L. Courtney, E. V. Lassakand and G. B. Speirs, Phytochemistry, 22, 1983, 947.

[15]. B. S. Siddiqui, S. Farhat and S. Siddiqui, Planta Medica, 63, 1997, 47.

[16]. Y. M. Chiang, J. Y. Chang, C. C. Kuo, C. Y. Chang and Y. H. Kuo, Phytochemistry, 66, 2005, $495-501$.

[17]. F. Matloubi, M. M. Farimani, S. Salahvarzi and G. Amin, Alternatative Medizin, 4 (1), 2007, 95-98

[18]. A. A. Bernard and L. Tokes, Journal of Organic Chemistry, 42(4), 1977, 725.

[19]. W. J. Li, W. Jain and Q. Y. Yang, World Journal of Gastroenterology, 8(3), 2002, 493-495.

[20]. Faten, K.; Hady, A. El.; Ahmed, G. Zeischrift fur Naturforschung, 2002, 57(c), 386-394.

[21]. G. R. Waller, Biochemical Application of Mass Spectrometry, (John Wiley and Sons, New York, USA, 1980$) 396$.

[22]. M. Tamai, N. Watanabe, M. Someya, H. Konadoh, S. Omura, Z. P. ling, R. Chang and C. Weiming, C. Planta Medica, 55, 1989, 44-47.

[23]. R. Tanaka and S. Matsunaga, Phytochemistry, 27, 1988, 3579.<smiles>C=C(C)C1CC[C@]2(CCO)CC[C@]3(C)C(CCC4[C@@]5(C)CC[C@@H](O)C(C)(C)[C@@H]5CC[C@]43C)C12</smiles>

(Figure 1)

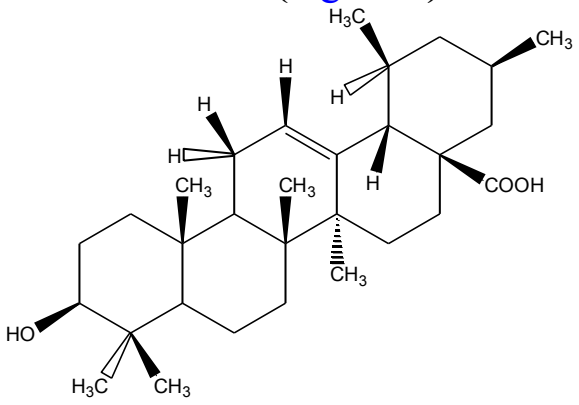

(Figure 3)

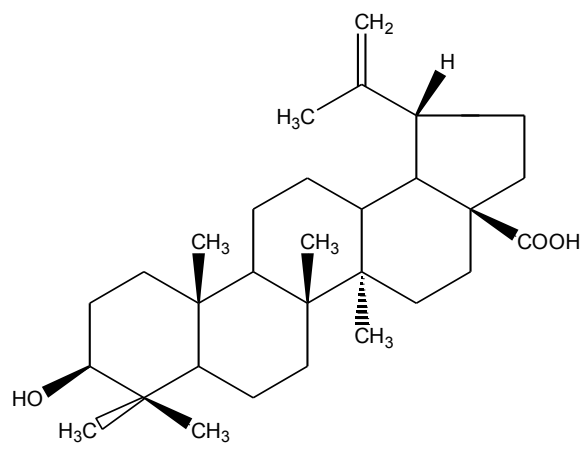<smiles>CC1(C)CC[C@@]2(O)CC[C@]3(C)C(=CCC4[C@@]5(C)CC[C@H](O)C(C)(C)C5CC[C@]43C)C2C1</smiles>

(Figure 2)

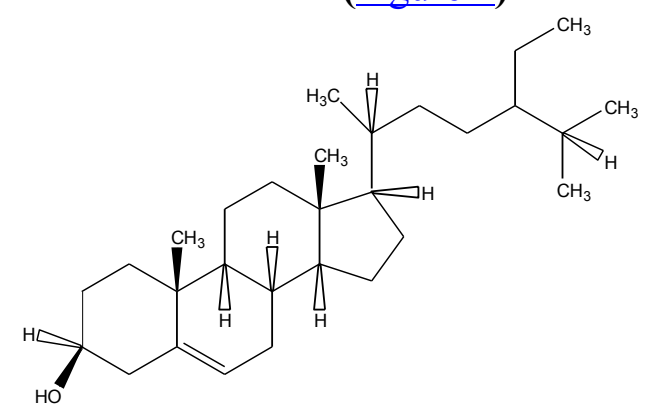

(Figure 4)

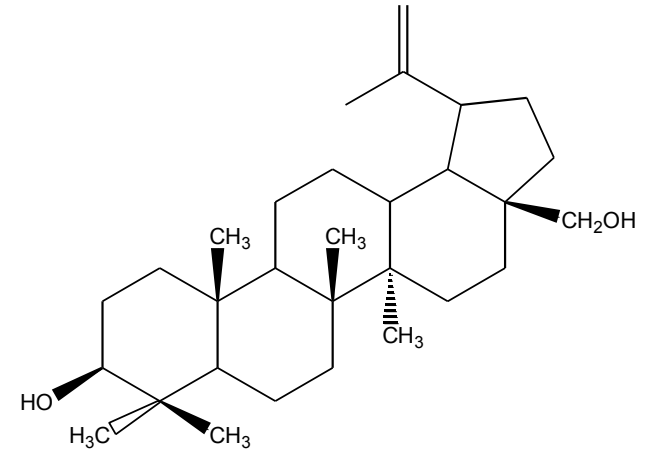


(Figure 5)

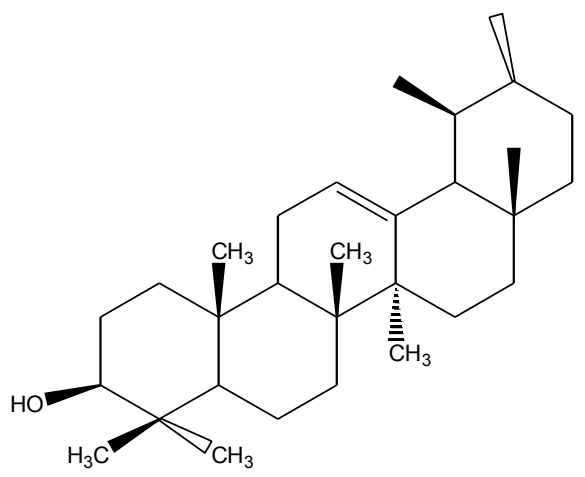

(Figure 7)
(Figure 6)

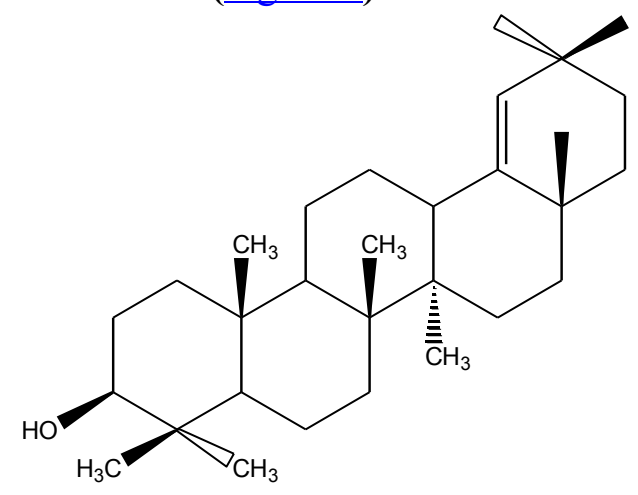

(Figure 8)

Table 1, ${ }^{13} \mathrm{C}$-NMR Chemical Shifts Assignments ( $\delta$ ) for compounds 1-8

\begin{tabular}{|c|c|c|c|c|c|c|c|c|}
\hline \multirow{2}{*}{$\begin{array}{c}\text { Carbon } \\
\text { No. }\end{array}$} & \multicolumn{8}{|c|}{ Compounds } \\
\hline & 1 & 2 & 3 & 4 & 5 & 6 & 7 & 8 \\
\hline $1-C$ & 150.37 & 38.41 & 180.51 & 37.26 & 179.79 & 38.73 & 40.03 & 38.5 \\
\hline $2-C$ & 109.69 & 27.17 & 138.061 & 31.68 & 150.38 & 27.08 & 27.31 & 24.4 \\
\hline $3-C$ & 79.02 & 79.01 & 77.20 & 71.81 & 109.68 & 78.89 & 79.08 & 79.0 \\
\hline $4-C$ & 68.19 & 39.25 & 63.37 & 42.32 & 79.00 & 38.87 & 39.7 & 39.0 \\
\hline $5-C$ & 56.21 & 55.203 & 47.68 & 140 & 56.27 & 55.3 & 55.22 & 55.7 \\
\hline $6-\mathrm{C}$ & 55.43 & 18.31 & 41.93 & 121.7 & 55.36 & 18.31 & 18.38 & 18.3 \\
\hline $7-\mathrm{C}$ & 50.61 & 32.67 & 39.33 & 31.68 & 50.53 & 34.26 & 32.98 & 34.7 \\
\hline $8-C$ & 49.35 & 37.04 & 36.79 & 31.91 & 49.29 & 40.95 & 40.08 & 40.9 \\
\hline $9-C$ & 46.87 & 47.603 & 125.35 & 50.15 & 46.88 & 50.43 & 47.76 & 51.3 \\
\hline $10-C$ & 42.49 & 38.74 & 78.72 & 36.51 & 42.45 & 37.18 & 37.18 & 37.3 \\
\hline $11-C$ & 40.77 & 23.04 & 55.12 & 21.09 & 40.71 & 20.08 & 23.39 & 21.2 \\
\hline $12-C$ & 38.89 & 122.67 & 52.70 & 42.32 & 38.86 & 25.24 & 124.46 & 26.2 \\
\hline $13-C$ & 38.78 & 143.53 & 47.43 & 14.09 & 38.72 & 37.34 & 139.62 & 39.0 \\
\hline $14-C$ & 38.41 & 41.69 & 38.95 & 56.78 & 38.39 & 42.74 & 41.78 & 43.4 \\
\hline $15-C$ & 37.26 & 27.67 & 38.76 & 24.30 & 37.22 & 27.42 & 28.0 & 27.6 \\
\hline $16-C$ & 37.01 & 23.04 & 38.53 & 28.24 & 37.01 & 29.20 & 26.65 & 37.4 \\
\hline $17-C$ & 34.40 & 46.42 & 36.68 & 56.07 & 34.34 & 28.009 & 33.78 & 34.4 \\
\hline $18-\mathrm{C}$ & 32.17 & 41.179 & 32.90 & 11.97 & 32.15 & 47.81 & 59.11 & 142.8 \\
\hline $19-C$ & 30.57 & 45.87 & 30.53 & 19.38 & 30.56 & 48.80 & 39.69 & 129.8 \\
\hline $20-C$ & 29.73 & 30.66 & 26.71 & 36.14 & 29.98 & 150 & 39.64 & 32.3 \\
\hline $21-C$ & 28.01 & 33.79 & 24.07 & 19.03 & 27.70 & 29.78 & 31.28 & 33.4 \\
\hline $22-C$ & 27.46 & 32.39 & 23.12 & 33.96 & 27.41 & 33.98 & 41.56 & 37.7 \\
\hline $23-C$ & 25.57 & 28.08 & 18.16 & 29.68 & 25.51 & 37.99 & 15.62 & 28.0 \\
\hline $24-C$ & 22.97 & 15.54 & 27.89 & 45.85 & 20.86 & 15.34 & 15.68 & 15.4 \\
\hline $25-C$ & 20.91 & 15.3 & 23.34 & 29.17 & 19.37 & 16.10 & 16.9 & 16.1 \\
\hline $26-C$ & 19.39 & 17.00 & 20.95 & 18.77 & 18.29 & 15.99 & 17.48 & 16.7 \\
\hline $27-C$ & 18.33 & 25.87 & 16.81 & 19.80 & 16.11 & 14.77 & 28.4 & 14.6 \\
\hline $28-C$ & 16.13 & 180.06 & 16.72 & 23.08 & 16.03 & 60.59 & 28.76 & 25.3 \\
\hline $29-C$ & 16.05 & 32.67 & 15.42 & 11.85 & 15.33 & 19.09 & 23.4 & 31.3 \\
\hline $30-C$ & 15.34 & 23.39 & 15.22 & - & 14.69 & 110 & 21.37 & 29.2 \\
\hline $31-C$ & 14.71 & - & - & - & - & - & - & - \\
\hline
\end{tabular}


In Vitro Antifungal Bioassay of Hexane Fraction

\begin{tabular}{|c|c|c|c|c|c|}
\hline \multirow{2}{*}{ Name of the Fungus } & \multicolumn{2}{|c|}{ Linear growth $(\mathrm{mm})$} & \multirow{2}{*}{$\begin{array}{c}\% \\
\text { Inhibition }\end{array}$} & \multirow{2}{*}{$\begin{array}{l}\text { Std. Drugs } \\
\mathrm{MIC} \mu \mathrm{g} / \mathrm{mL}\end{array}$} & \multirow{2}{*}{$\begin{array}{l}\% \text { Inhibition } \\
\text { of Std. Drug }\end{array}$} \\
\hline & Sample & Control & & & \\
\hline Aspergillus flavus & 100 & 100 & 0 & Amphotericin B & 20 \\
\hline Candida glaberata & 100 & 100 & 0 & Miconazole & 78.3 \\
\hline Candida albicans & 100 & 100 & 0 & Miconazole & 78.3 \\
\hline Fusarium solani & 25 & 100 & 65 & Miconazole & 62.1 \\
\hline Microsporum canis & 60 & 100 & 40 & Miconazole & 91.3 \\
\hline Trichophyton longifusus & 50 & 100 & 30 & Miconazole & 27 \\
\hline
\end{tabular}

Key: Concentration of sample $400 \mu \mathrm{g} / \mathrm{mL}$ of DMSO Incubation temp. $27\left(28 \pm 1{ }^{\circ} \mathrm{C}\right)$

In Vitro Antifungal Bioassay of Ethyl Acetate Fraction

\begin{tabular}{|c|c|c|c|c|c|}
\hline \multirow{2}{*}{ Name of the Fungus } & \multicolumn{2}{|c|}{ Linear growth (mm) } & \multirow{2}{*}{$\begin{array}{c}\% \\
\text { Inhibition }\end{array}$} & \multirow{2}{*}{$\begin{array}{l}\text { Std. Drugs } \\
\mathrm{MIC} \mu \mathrm{g} / \mathrm{mL}\end{array}$} & \multirow{2}{*}{$\begin{array}{l}\% \text { Inhibition } \\
\text { of Std. Drug }\end{array}$} \\
\hline & Sample & Control & & & \\
\hline Aspergillus flavus & 30 & 100 & 50 & Amphotericin B & 20 \\
\hline Candida glaberata & 100 & 100 & 0 & Miconazole & 69.03 \\
\hline Candida albicans & 100 & 100 & 0 & Miconazole & 69.03 \\
\hline Fusarium solani & 50 & 100 & 50 & Miconazole & 40 \\
\hline Microsporum canis & 60 & 100 & 40 & Miconazole & 91.3 \\
\hline Trichophyton longifusus & 50 & 100 & 50 & Miconazole & 60 \\
\hline
\end{tabular}

Key: Concentration of sample $400 \mu \mathrm{g} / \mathrm{mL}$ of DMSO Incubation temp. $27\left(28 \pm 1{ }^{\circ} \mathrm{C}\right)$

In Vitro Antifungal Bioassay of Chloroform Fraction

\begin{tabular}{|c|c|c|c|c|c|}
\hline \multirow{2}{*}{ Name of the Fungus } & \multicolumn{2}{|c|}{ Linear growth (mm) } & \multirow{2}{*}{$\begin{array}{c}\% \\
\text { Inhibition } \\
\end{array}$} & \multirow{2}{*}{$\begin{array}{l}\text { Std. Drugs } \\
\mathrm{MIC} \mu \mathrm{g} / \mathrm{mL}\end{array}$} & \multirow{2}{*}{$\begin{array}{l}\% \text { Inhibition } \\
\text { of Std. Drug }\end{array}$} \\
\hline & Sample & Control & & & \\
\hline Aspergillus flavus & 100 & 100 & 0 & Amphotericin B & 15 \\
\hline Candida glaberata & 100 & 100 & 0 & Miconazole & 60.01 \\
\hline Candida albicans & 100 & 100 & 0 & Miconazole & 60.01 \\
\hline Fusarium solani & 50 & 100 & 50 & Miconazole & 63.17 \\
\hline Microsporum canis & 60 & 100 & 40 & Miconazole & 92 \\
\hline Trichophyton longifusus & 60 & 100 & 40 & Miconazole & 73 \\
\hline
\end{tabular}

Key: Concentration of sample $400 \mu \mathrm{g} / \mathrm{mL}$ of DMSO Incubation temp. $27\left(28 \pm 1{ }^{\circ} \mathrm{C}\right)$

In Vitro Antifungal Bioassay of Methanol Fraction

\begin{tabular}{|c|c|c|c|c|c|}
\hline \multirow{2}{*}{ Name of the Fungus } & \multicolumn{2}{|c|}{ Linear growth $(\mathrm{mm})$} & \multirow{2}{*}{$\begin{array}{c}\% \\
\text { Inhibition } \\
\end{array}$} & \multirow{2}{*}{$\begin{array}{c}\text { Std. Drugs } \\
\mathrm{MIC} \mu \mathrm{g} / \mathrm{mL}\end{array}$} & \multirow{2}{*}{$\begin{array}{l}\% \text { Inhibition } \\
\text { of Std. Drug }\end{array}$} \\
\hline & Sample & Control & & & \\
\hline Aspergillus flavus & 80 & 100 & 20 & Amphotericin B & 15 \\
\hline Candida glaberata & 100 & 100 & 0 & Miconazole & 98.9 \\
\hline Candida albicans & 100 & 100 & 0 & Miconazole & 98.9 \\
\hline Fusarium solani & 80 & 100 & 20 & Miconazole & 77.25 \\
\hline Microsporum canis & 40 & 100 & 60 & Miconazole & 95.2 \\
\hline Trichophyton longifusus & 50 & 100 & 50 & Miconazole & 70 \\
\hline
\end{tabular}

Key: Concentration of sample $400 \mu \mathrm{g} / \mathrm{mL}$ of DMSO Incubation temp. $27\left(28 \pm 1{ }^{\circ} \mathrm{C}\right)$ 